\title{
KUALITAS MIKROBIOLOGI CACING LAOR (Polychaeta) DARI PERAIRAN PANTAI LAWENA, DESA HUTUMURY KOTA AMBON
}

\author{
Meigy Nelce Mailoa ${ }^{1 \star}$, Raja Bonan Dolok Sormin ${ }^{1}$, Joel Lewaherilla ${ }^{2}$ \\ ${ }^{1}$ Program Studi Teknologi Hasil Perikanan, Fakultas Perikanan dan Ilmu Kelautan \\ ${ }^{2}$ Laboratorium Teknologi Hasil Perikanan, Fakultas Perikanan dan Ilmu Kelautan \\ Universitas Pattimura, Kampus Unpatti-Poka \\ Jalan Mr. Chr. Soplanit Poka 97233 Ambon Maluku \\ Telepon. (0911) 3825060, faks. (0911) 3825061 \\ ^Korespondensi: meigy_mailoa@yahoo.com; meigy.mailoa@fpik.unpatti.ac.id \\ Diterima: 6 April 2020/ Disetujui: 16 Agustus 2020
}

Cara sitasi: Mailoa MN, Sormin RBD, Lewaherilla J. 2020. Kualitas mikrobiologi cacing laor (Polychaeta) dari Perairan Pantai Lawena, Desa Hutumury Kota Ambon. Jurnal Pengolahan Hasil Perikanan Indonesia. 23(2): 352-358

\begin{abstract}
Abstrak
Cacing laor merupakan organisme yang berada di dasar perairan, maka pada saat tertentu dimungkinkan akan terkontaminasi oleh bakteri patogen. Penelitian ini bertujuan untuk menentukan karakteristik mutu cacing laor. Morfologi dan uji biokimia terhadap isolat Vibrio sp. dari cacing laor ditentukan. Total bakteri yang terkandung pada cacing laor segar sebesar $1,2 \times 10^{4}-1,6 \times 10^{4} \mathrm{CFU} / \mathrm{g}$ dan total

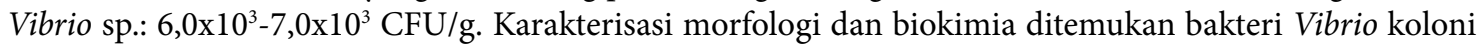
berbentuk bulat (isolat $\mathrm{Vb} 1, \mathrm{Vb} 2, \mathrm{Vb} 3$ dan $\mathrm{Vb} 6, \mathrm{Vb} 4$ ), isolat $\mathrm{Vb} 5$ memiliki bentuk koloni tidak beraturan, berwarna kuning dengan tekstur yang halus. Hasil interpretasi uji katalase kedua isolat menunjukkan hasil positif dan pengecatan Gram isolat Vibrio : Gram negatif. Temuan ini dapat berfungsi sebagai dasar untuk pengujian mikrobiologi lanjutan terkait patogenitas bakteri yang diisolasi dari cacing laor.
\end{abstract}

Kata kunci: keamanan pangan, kesehatan masyarakat, kontaminasi, Vibrio sp.

\section{Microbiologicaly Quality Of "Laor" Worms (Polychaeta) From Lawena Beach, Village Hutumury Ambon City}

\begin{abstract}
"Laor" worms are organisms living on the seabeds and are possibly contaminated by pathogenic bacteria. This study was aimed to determine the microbiological quality characteristics of "laor" worms. Morphological characterization and biochemical tests on the Vibrio sp isolates of "laor" worms were conducted. The result showed the total bacteria and Vibrio sp. in fresh "laor" worms were $1.2 \times 10^{4} 1.6 \times 10^{4}$ $\mathrm{CFU} / \mathrm{g}$ and $6.0 \times 10^{3}-7.0 \times 10^{3} \mathrm{CFU} / \mathrm{g}$ respectively. Morphological and biochemical characterization showed that isolates of Vibrio colonies (Vb1, Vb2, Vb3, Vb4 and Vb6 isolates) were rounded shape, except the Vb5 isolate having irregular colony shape and yellow colored with a smooth texture. The Vibrio isolate was Gram negative and showing positive result on catalase test. This finding can be used as a basis for subsequent microbiological testing related to bacterial pathogenicity isolated from "laor" worms.
\end{abstract}

Keywords: contamination, food safety, public health, Vibrio sp. 


\section{PENDAHULUAN}

Cacing laut (Polychaeta) biasanya muncul di permukaan laut saat musim kawin, karena sistem perkembangbiakannya secara eksternal dengan periode waktu setahun sekali di bulan Maret atau April. Hewan ini biasanya ditangkap menggunakan "tanggu" di daerah pantai berkarang oleh penduduk lokal guna dijadikan bahan pangan. Masyarakat Maluku khususnya pulau Ambon sejak dahulu telah mengenal dan mengonsumsi cacing laut (Polychaeta) atau "Laor" (Radjawane 1982) yang telah diolah menjadi "bakasang laor"dan "lawar laor". Menurut Pamungkas (2009) cacing laut ini dikenal dengan nama cacing "wawo" yang muncul ke permukaan perairan satu kali dalam setahun saat malam purnama atau beberapa hari setelahnya.

Beberapa penelitian cacing laut dengan berbagai spesies yang ada di Indonesia sudah dikaji menurut aspek biologis yaitu struktur komunitas serta ciri substrat cacing laut asal perairan hutan mangrove Kalimantan Barat (Junardi dan Wardoyo 2008); komunitas cacing laut di perairan Nusa Tenggara Timur (Widianwari dan Widianingsih 2011); kandungan asam amino, asam lemak, dan mineral cacing laut dari Sulawesi Tenggara (Nurhikma et al. 2017). Latumahina (2011) dalam kajiannya menyatakan bahwa cacing laor dari perairan pulau Ambon hidup pada salinitas $32 \%, \mathrm{pH}$ 8-10, DO 5,9. Dalam kaitan pemanfaatan cacing laut sebagai pakan induk ikan hias juga telah berhasil dilakukan Ignatius et al. (2001), selanjutnya Coman et al. (2007); Hermawan et al. (2015) juga telah membuat pakan alami dari cacing laut untuk udang windu. Beberapa penelitian sudah menginformasikan komponen gizi cacing laor asal perairan kota Ambon dan Maluku telah dipublikasikan oleh Tampubolon et al. (2007) kadar protein laor (Eunice viridis) segar 13,73\%; Savitri et al. (2008) kadar protein cacing laor asal kepulauan Kei Maluku Tenggara memiliki kadar protein sebesar 13,85\%; Latumahina (2011) menganalisis kandungan protein cacing laor asal desa latuhalat sebesar 13,92\%; Latumahina dan Mailoa (2016) melaporkan yodium yang terkandung pada cacing laor sangat berguna untuk pertumbuhan, sistem kekebalan tubuh dan pertumbuhan janin dalam kandungan; Liline (2017) melaporkan kandungan protein cacing laor yang diambil dari 3 lokasi perairan di kota ambon menunjukkan nilai bervariasi yakni kandungan protein cacing laor asal desa Hutumuri sebesar (10,55\%), desa Latuhalat $(14,29 \%)$ dan desa Alang (15,05\%).

Kandungan protein yang tinggi pada cacing laor merupakan media yang baik untuk pertumbuhan bakteri sehingga rentan terhadap kerusakan mikrobiologi. Rantai pengolahan ikan dan hasil laut untuk menghasilkan produk yang bermutu maka perlu diperhatikan dasar pengetahuan ilmiah tentang bahaya mikrobiologis dan pemahaman tentang produksi primer, teknologi pengolahan, manufaktur dan penanganan selama persiapan makanan, penyimpanan dan transportasi, ritel dan katering (Reilly 2006). Sari dan Apridamayanti (2014) menegaskan bahwa makanan laut yang dikonsumsi dapat menjaga kesehatan jantung orang dewasa dan pengembangan visual bagi bayi dan anak-anak, tetapi, makanan laut juga dapat membawa risiko bagi kesehatan bila telah terkandung bakteri patogen. Menurut Baffone et al. (2000), produk makanan laut yang dipanen dari perairan yang terkontaminasi dan diawetkan secara tidak benar setelah panen, ditemukan Vibrio spp. yang dapat menyebabkan infeksi.

Konsumsi makanan laut mentah atau setengah matang, yang terkontaminasi $V$. parahaemolyticus dapat menyebabkan pengembangan gastroenteritis akut yang ditandai dengan diare, sakit kepala, muntah, mual, keram perut, dan demam rendah (Pal 2007). Bakteri ini diakui sebagai penyebab utama gastroenteritis manusia yang terkait dengan konsumsi makanan laut di Amerika Serikat, dan patogen yang ditularkan dari hasil laut di seluruh dunia (Su dan Liu 2007). Kontaminasi sering terjadi dari sumber manusia dan hewan, dengan demikian ikan dan makanan laut dapat terlibat dalam transmisi mikroorganisme patogen dan racun (Pal 2012). Diperkirakan ada lebih dari 80 juta kasus penyakit yang ditularkan melalui makanan laut di AS yang resistensi antibiotik dan biaya penyakit ini mencapai miliaran dolar per tahun (Adebayo-Tayo et al. 2012). 
Kerugian ekonomi akibat pembusukan pangan jarang dikuantifikasi tetapi sebuah laporan oleh Komite Dewan Riset Nasional AS (FND/NRC) memperkirakan bahwa seperempat dari pasokan pangan dunia rusak karena aktivitas mikroba itu sendiri (EEC 1992). Mengingat cacing laor ini merupakan organisme yang hidup di dasar perairan, sehingga saat-saat tertentu misalnya terjadinya blooming maka perairan akan menjadi subur sehingga memungkinkan cacing laor dapat terkontaminasi mikroba pathogen yang bersifat fagositer sehingga dalam kondisi tersebut biota laut ini sangat bahaya jika dikonsumsi oleh manusia. Adanya kontrol kualitas makanan laut bertujuan untuk menghindari kontaminasi mikroba yang tinggi, dan menyebabkan resistensi antibiotik,maka perlu didokumentasikan dengan baik karena tingkat penyakit yang ditularkan melalui makanan laut meningkat, sehingga analisis mutu mikrobiologis perlu dilakukan untuk memastikan kualitas makanan laut (Adebayo-Tayo et al. 2012).

Sebagian besar karya yang dipublikasikan mengenai kontaminasi mikroba makanan laut umumnya berkonsentrasi pada ikan dan seafood, sehingga penelitian cacing "laor" segar asal perairan Kota Ambon sebagai objek analisis kualitas mikrobiologisnya perlu dilakukan. Penelitian ini bertujuan untuk menentukan karakteristik mutu mikrobiologi cacing laor.

\section{BAHAN DAN METODE Bahan dan Alat}

Sampel cacing laor yang diambil di perairan Pantai Lawena, Desa Hukurila, Ambon. Bahan kimia yang digunakan yaitu Natrium Clorida ( $\mathrm{NaCl}$ 0,9\%) (Riedel-de Haen), $\mathrm{CaCO}_{3} 1 \%$ (merck), $\mathrm{H}_{2} \mathrm{O}_{2} 3 \%$ (merck), alkohol 70\% (one-med), larutan cat Hucker's crystal violet (Gram A) (merck), larutan mordan Lugol's iodine (Gram B) (merck), larutan alkohol (Gram C) (one-med), larutan cat Safranin (Gram D) (merck), akuades (Aqua DM-PT. Brataco), kertas label, spirtus, media agar: PCA (Merck). TCBS Agar (Difco), Medium DeMan Ragosa Sharpe (MRS Agar) (Difco), MRS Broth (Difco), Nutrien Agar (NA) (Difco), Nutrient Broth. Alat yang digunakan yaitu botol, kapas, pinset, plastik sampel, coolbox, timbangan analitik, mikroskop, inkubator (Isuzu Incubator; SSJ115), autoklaf (Autoklaf All American 75X), desikator, petridis (pyrex), tabung reaksi (pyrex) oven (Memmert), jarum inokulasi, bunsen, spatula, pipet steril.

\section{Metode Penelitian}

Tahapan penelitian yang dilakukan terdiri atas 2 tahap. Tahap pertama yaitu koleksi sampel cacing laor segar diambil dari peraian pantai Lawena Desa Hutumury pada bulan april 2020, sampel ditempatkan dalam kantong plastik steril dan dibawa ke laboratorium Teknologi Hasil Perikanan FPIK-UNPATTI untuk analisis mikrobiologis. Tahap kedua yaitu analisa mikrobiologi yang meliputi: total mikroba, isolasi dan karakteristik bakteri Vibrio, selanjutnya dilakukan uji karakterisasi morfologi dan biokimia.

\section{Total mikroba}

Analisis mikrobiologi pada sampel cacing laor yaitu penentuan total plate count (TPC) dan total Vibrio menggunakan metode pour plate berdasarkan SNI 01-2332.3-2006.

\section{Isolasi bakteri Vibrio sp.}

Bakteri Vibrio sp diisolasi dengan menggunakan teknik pengenceran kemudian diinokulasi dengan metode pour plate pada media TCBS agar (Lay 1994). Inokulan diinkubasi selama 24 jam dengan temperatur $37^{\circ} \mathrm{C}$. Koloni yang dicurigai sebagai bakteri Vibrio sp diambil dengan menggunakan jarum Ose dipindahkan dengan teknik streak plate pada media TCBS agar, diinkubasi pada suhu $37^{\circ} \mathrm{C}$. Pengamatan ciri morfologi isolat Vibrio dilakukan dengan menggunakan mikroskop pembesaran 400x.

\section{Karakterisasi Morfologi}

Karakteristik morfologi isolat bakteri dilakukan pengamatan secara mikroskopik (menggunakan mikroskop) pembesaran 400x seperti bentuk dan warna sel dan makroskopis (mata telanjang), karakteristik koloni bakteri yaitu bentuk koloni, elevasi, bentuk tepi, struktur dalam. 


\section{Pewarnaan gram}

Karakterisasi biokimia Vibrio sp dari cacing laor berupa Pengujian sifat morfologi sel isolat bakteri dilakukan dengan pewarnaan Gram (Cappucino dan Sherman 1992). Tahapan uji Gram bakteri sebagai berikut: akuades steril ditetesi kurang lebih 1-2 tetes di atas kaca objek, kemudian diambil satu Ose koloni dari media agar disebarkan sampai merata diatas kaca objek selanjutnya difiksasi hingga kering. Setelah olesan kering ditetesi dengan larutan kristal ungu (Gram A), dan biarkan selama 60 detik, kemudian bilas dengan akuades dan dikeringkan. Selanjutnya ditetesi dengan larutan iodium (Gram B) dan dibiarkan selama 120 detik, dibilas lagi menggunakan akuades dan dikeringkan. Kemudian ditetesi dengan larutan etanol 95\% (Gram C) selama 30 detik, dibilas dengan akuades dan dikeringkan. Setelah itu ditetesi zat penutup atau larutan safranin (Gram D) dibiarkan selama 30 detik, setelah itu dicuci lagi dengan akuades dan dikeringkan. Kaca Ojek diamati di bawah mikroskop dengan perbesaran 400x. Isolat bakteri yang menunjukkan hasil perwarnaan violet atau ungu yaitu Gram positif sedangkan berwarna merah merupakan bakteri Gram negatif.

\section{Uji Katalase}

Pengujian katalase pada isolat bakteri dilakukan untuk mengetahui kemampuan enzim katalase yang diproduksinya (Lay 1994). Hal ini ditunjukkan lewat respons positif dari kultur isolat (berumur 24 jam) yang diberi $\mathrm{H}_{2} \mathrm{O}_{2} 3 \%$ sekitar 2 tetes akan menunjukkan gelembung-gelembung gas sebagai hasil pembentukan gas oksigen $\left(\mathrm{O}_{2}\right)$ dari pemecahan $\mathrm{H}_{2} \mathrm{O}_{2}$ oleh aktifitas enzim katalase yang diproduksi oleh bakteri tersebut.

\section{Analisis Data}

Analisis data secara deskriptif ditampilkan dalam bentuk gambar dan tabel. Data angka lempeng total mikroba dibandingkan dengan standar mutu mikrobiologi ikan segar (BSN 2006).

\section{HASIL DAN PEMBAHASAN Total Bakteri}

Total dan keragaman mikroba pada biota laut tergantung pada lokasi geografis, musim dan metode panen. Secara umum, mikroflora ikan cenderung mencerminkan komunitas mikroba di perairan sekitarnya (Rhea 2009). Berdasarkan hasil analisis total bakteri pada cacing laor segar diketahui bahwa total koloni bakteri sebesar $1,2 \times 10^{4}-1,6 \times 10^{4} \mathrm{CFU} / \mathrm{g}$ sedangakan total Vibrio berkisar dari $6,0 \times 10^{3}-$ $7,0 \times 10^{3} \mathrm{CFU} / \mathrm{g}$. Bila dibandingkan dengan Standar Nasional Indonesia ikan segar jumlah maksimum total mikroba yaitu $5,0 \times 10^{5} \mathrm{CFU} / \mathrm{g}$ maka, cacing laor masih aman dikonsumsi.

Vibrio sp. adalah patogen oportunis yang terdapat pada ekosistem muara dan lingkungan laut. Keberadaan Vibrio sp penyebab foodborne illness perlu diperhatikan, salah satunya $V$. alginolitycus merupakan bakteri yang berperan dalam proses pembusukan pada produk seafood.

\section{Karakterisasi Isolat Vibrio sp}

Karakterisasi bakteri diawali dengan isolasi bakteri Vibrio. Sifat morfologi koloni dan sel Isolat Vibrio sp pada cacing laor (Table 1), pertumbuhan Vibrio pada medium TCBS agar seperti yang ditampilkan Figure 1 .

Table 1 Characteristics of colony morphology and Vibrio isolate cells

\begin{tabular}{|c|c|c|c|c|}
\hline \multirow{2}{*}{ Isolate Code } & \multicolumn{2}{|c|}{ Morphological Characteristics of the Colonies } & \multicolumn{2}{|c|}{ Morphological Characteristics of Cell } \\
\hline & Color & Colony Shape & Cell Shape & Color \\
\hline $\mathrm{Vb} 1$ & yellow & circular & bacil, coma & Gram negative \\
\hline $\mathrm{Vb} 2$ & yellow & circular & bacil, coma & Gram negative \\
\hline $\mathrm{Vb} 3$ & yellow & circular & bacil & Gram negative \\
\hline $\mathrm{Vb} 4$ & yellow & irreguler & bacil & Gram negative \\
\hline Vb 5 & yellow & irreguler & bacil & Gram negative \\
\hline Vb 6 & yellow & circular & bacil & Gram negative \\
\hline
\end{tabular}




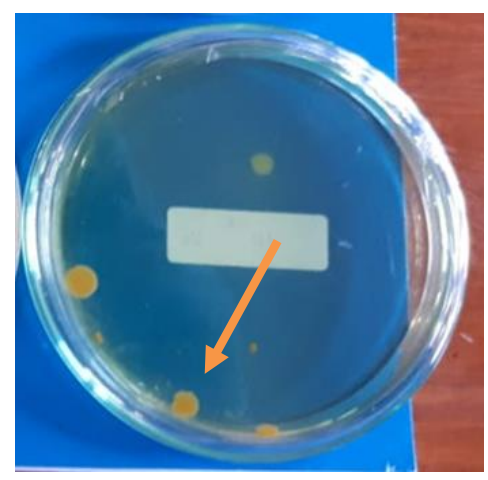

Figure 1 Vibrio sp. bacteria colonies on TCBS agar media

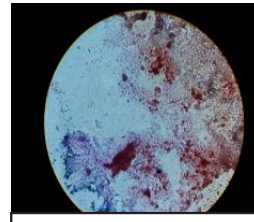

Isolat $\mathrm{Vb} 1$

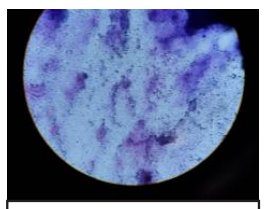

Isolat $\mathrm{Vb} 4$

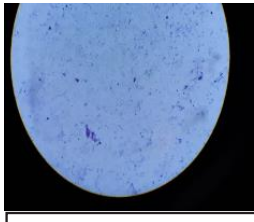

Isolat $\mathrm{Vb} 2$
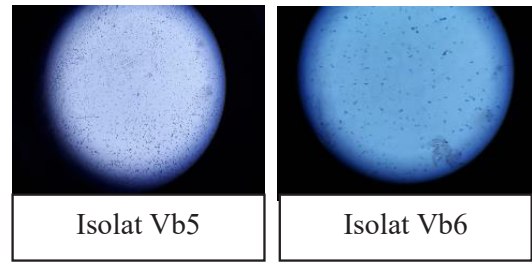

Figure 2 Gram staining of Vibrio sp. bacteria isolate from laor worms (400x magnification)

Berdasarkan hasil dari Karakteristik morfologi koloni bakteri, isolat $\mathrm{Vb} 1, \mathrm{Vb} 2$, Vb3 dan Vb6 memiliki bentuk bulat berwarna kuning, sedangkan Vb4 dan Vb5 memiliki bentuk koloni tidak beraturan dan berwarna kuning dengan tekstur yang halus. Fardiaz (1983) menyatakan bahwa bakteri Vibrio memfermentasi sukrosa menjadi asam ditunjukkan melalui penampakan warna kuning pada koloni yang tumbuh di media agar TCBS. Pewarnaan Gram isolat Vibrio sp yang didapat dari cacing laor dapat dilihat pada Figure 2.

Hasil Interpretas pengecatan Gram pada isolat ke enam isolat Vibrio; Gram negatif dengan bentuk batang, batang koma dan hasil uji katalase positif. Hasil ini, menunjukkan cacing laor juga mengandung Vibrio sp. Vibrio sp. umumnya ditemukan di lingkungan laut dan kadang-kadang ditemukan dalam produk makanan laut (Pramono et al. 2015). Makanan laut mentah atau kurang matang adalah sumber utama gastroenteritis yang disebabkan oleh Vibrio sp. (Alam et al. 2002; Tuyet et al. 2002; DePaola et al. 2003; Yang et al. 2008). Vibrio tertentu dalam sampel ikan laut, udang atau bivalvia yang dipanen dari Laut Adriatik, atau keberadaan mereka tergantung pada sumber sampel (Jaksic et al. 2002).

\section{KESIMPULAN}

Total bakteri yang terkandung pada cacing laor segar sebesar $1,2 \times 10^{4}-1,6 \times 10^{4}$ $\mathrm{CFU} / \mathrm{g}$, memenuhi standar mutu ikan segar

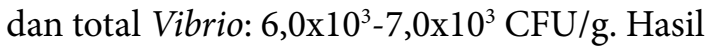
interpretasi karakteristik morfologi dan uji biokimia pada 6 isolat bakteri hasil isolasi dari cacing laor terdapat bakteri Vibrio sp.

\section{DAFTAR PUSTAKA}

Adebayo-Tayo AC, Odu NN, Michael MU, Okonko IO. 2012. Multi-drug resistant (MDR) organisms isolated from sea- 
foods in Uyo, South-Southern Nigeria. Nature and Science. 10(3): 61-70.

Alam MJ, Tomochika KI, Miyoshi SI, Shinoda S. 2002. Environmental investigationof potentially pathogen Vibrio parahaemolyticus in the Seto-Inland Sea, Japan. FEMS Microbiol Letters. 208(1): 83-87.

Baffone W, Pianetti A, Bruscolini F, Barbieri D, Citterio B. 2000: Occurrence and expression of virulence related properties of Vibrio species isolated from widely consumed seafood products. International Journal of Food Microbiology. 54(1): 9-18.

[BSN] Badan Standarisasi Nasional. 2006. Penentuan Angka Lempeng Total (ALT) pada Produk Perikanan -SNI 01-2332.32006. Jakarta (ID): Badan Standardisasi Nasional.

Cappucino JG, Sherman N. 1992. Microbiology, A Laboratory Manual. New York (AS): The Benjamin/Cummings Publishing Company.

Coman GJ, Arnold SJ, Callaghan TR, Preston NP. 2007. Effect of two maturation diet combinations on reproductive performance of domesticated Penaeus monodon. Aquaculture. 263(1): 75-83.

DePaola A, Ulaszek J, Kaysner CA, Tenge BJ, Nordstrom JL,Well J, Puhr N, Gendel SM, 2003. Molecular, serological, and virulence characteristics of Vibrio parahaemolyticus isolated from environmental, food, and clinical sources in North America and Asia. Applied Environmental Microbiolgy. 69(7): 3999-4005

[EEC] European Economic Community. 1992. Opinion of the scientific committee on veterinary measures relating to public health on Vibrio vulnificus and Vibrio parahaemolyticus (in raw and undercooked seafood).

Hermawan D, Saifullah, Herdiyana D. 2015, Pengaruh Perbedaan Jenis Substrat pada Pemeliharaan Cacing Laut (Nereis sp.) (The Effect of Different Substrat of Culture of Nereis sp.). Jurnal Perikanan dan Kelautan. 5(1): 41-47

Ignatius B. 2001. Spawning and larval rearingtechnique for tropical clownfish Amphiprion sebae under captive condition. Journal aquaculture Tropical. 16(3): 241-249.

Jaksic S, Uhitil S, Petrak T, Bazulic D, Karolyi LG. 2002. Occurrence of Vibrio spp. in sea fish, shrimps and bivalve molluscs harvested from Adriatic sea. Food Control. 13(8): 491-493.

Junardi, Wardoyo ERP. 2008. Struktur komunitas dan karakteristik substrat cacing laut (Polychaeta) di Perairan Pantai Mangrove Peniti, Kalimantan Barat. BIODIVERSITAS. 9(3): 213-216

Latumahina MChA. 2011. Pengolahan Dan Komposisi Gizi Cacing Polychaeta Di Pulau Ambon. [Prosiding Seminar Nasional]: Pengembangan Pulau-Pulau Kecil. Bogor (ID) Institut Pertanian Bogor.

Latumahina MChA, Mailoa MN. 2016. Iodine content and nutrition worms Polychaeta "laor" fresh and processed products. International Journal of ChemTech Research. 9(1): 147-150

Lay BW. 1994. Analisa Mikroba di Laboratorium. Jakarta (ID): Raja Grafindo Persada.

Liline S. 2017. Analisis kadar protein cacing laor (polychaeta) dari perairan pulau ambon. Biopendix. 3(2): 167-171

Pal M. 2012. Food spoilage. Ph.D. Lecture Notes. Addis Ababa University,College of Veterinary Medicine. Ethiopia (ET) : Debre Zeit.

Pal M. 2007. Zoonoses. $2^{\text {nd }}$ Ed. Jaipur India. India (IND): Satyam Publishers.

Pamungkas J. 2009. Pengamatan jenis cacing laor (annelida, Polychaeta) di perairan desa latuhalat Pulau ambon, dan aspek reproduksinya. Jurnal TRITON. 5(2):1-10

Pramono H, Noor HM, Fatimah SS, Harahap NA, Selia AA. 2015.isolasi dan identifikasi vibrio sp. Pada produk seafood tradisional area timur kota surabaya. Jurnal Ilmiah Perikanan dan Kelautan. 7(1):25-29

Radjawane TR.1982. Laor: Cacing Laut Khas Perairan Maluku, Lomba Karya Penelitian Ilmiah Remaja, Jakarta (ID): Departemen 
Pendidikan dan Kebudayaan Republik Indonesia.

Reilly A. 2006. Managing Microbiological Risk in the Fish Processing Chain. In: FAO EUROFISH Workshop on Seafood Safety, Copenhagen, December 13-15, 2006.

Rhea F. 2009. Microbiology handbook: Fish and seafood. Leatherhead Food. UK (US) : International Ltd. Surrey.

Sari R, Apridamayanti P. 2014 . Cemaran bakteri Eschericia coli dalam beberapa makanan laut yang beredar di pasar tradisional kota pontianak. Kartika Jurnal Ilmiah Farmasi. 2 (2): 14-19

Savitri IKE, Latumahina M, Tapotubun AM. 2008. Studi Kandungan Gizi Laor. [Prosiding Seminar Nasional Perikanan dan Kelautan], Malang (ID): Fakultas Perikanan dan Kelautan Universitas Brawijaya.

$\mathrm{Su}$ YC, Liu C. 2007. V. parahaemolyticus: a concernof seafood safety. Food Microbiology. 24 (6): 549-558

Tampubolon K, Purnomo D, Sangadji M. 2007. Pengolahan pasta laor (Eunice viridis) dengan berbagai konsentrasi garam. Buletin Teknologi Hasil Perikanan. 10 (1):47-58.

Tuyet DT, Thiem VD, Von Seidlein L, Chowdhury A, Park E, Canh DG, Chien BT,Van Tung T, Naficy A, Rao MR, Ali M, Lee H, Sy TH, Nichibuchi M, Clemens J, Trach DD. 2002. Clinical, epidemiological, and socioeconomic analysis of anoutbreak of Vibrio parahaemolyticus in Khanh Hoa Province, Vietnam. The Journal Infectious Diseases.186: 1615-1620

Widianwari P dan Widianingsih, 2011. Komunitas Cacing Laut Dalam (Polychaeta) di Selat Flores, Lamakera dan Alor, Nusa Tenggara Timur. Ilmu Kelautan. 16 (4): 219-228

Yang, ZQ, Jiao XA, Zhou XH, Cao GX, Fang WM, Gu RX.2008. Isolation and molecular characterization of Vibrio parahaemolyticus from fresh, lowtemperature preserved, dried, and salted seafood products in two coastal areas of eastern China. International Journal of Food Microbiology. 125(3):279-285. 